\title{
Interaction genotype by season and its influence on the identification of beans with high content of zinc and iron
}

\author{
Camila Andrade Silva (1*); Ângela de Fátima Barbosa Abreu (2); Magno Antonio Patto Ramalho ('); \\ Angelita Duarte Corrêa ( $\left.{ }^{3}\right)$
}

(') Universidade Federal de Lavras (UFLA), Departamento de Biologia, Programa de Pós-graduação em Genética e Melhoramento de Plantas, Caixa Postal 3037, 37200-000 Lavras (MG), Brasil.

(2) Empresa Brasileira de Pesquisa Agropecuária (Embrapa), Centro de Pesquisa Arroz e Feijão/UFLA, Departamento de Biologia, 37200-000 Lavras (MG), Brasil.

(3) UFLA, Departamento de Química, 37200-000 Lavras (MG), Brasil.

(*) Corresponding author: camilaagro01@yahoo.com.br

Received: Mar. 13, 2012; Accepted: Aug. 24, 2012

\begin{abstract}
The mineral contents in common bean seeds are influenced, in addition to genetic variation, by environmental crop conditions, especially by the soil type and chemical composition and by the genotype $x$ environment interaction. This study was carried out to verify if the zinc and iron contents are affected by the crop growing period. Ten lines with high iron and zinc contents and ten with low contents were assessed in three seasons: "wet season" of 2009/2010 (sowing in November); "dry season" of 2010 (sowing in February) and "winter season” of 2010 (sowing in July), in Lavras, Minas Gerais State, Brazil. The experimental design used was randomized blocks with three replications and plots consisting of two rows of two meters, with a spacing of $0.50 \mathrm{~m}$. The seeds harvested were assessed in regard to iron and zinc mineral contents. The greatest contents were observed in the winter season and the smallest ones in the dry season, with sowing in February. It was observed that in the mean of the three harvests, the lines classified as having high iron and zinc content exhibited an iron quantity $11.0 \%$ and a zinc quantity $6.8 \%$ above those of low content. The lines by seasons interaction occurs. However, its interference in identification of the groups with high and low content of the two nutrients is not great.
\end{abstract}

Key words: Phaseolus vulgaris L.; nutritional quality; seasonality.

\section{Interação genótipos $x$ ambiente e sua influência na identificação de linhagens de feijão comum com alto teor de zinco e ferro}

\section{Resumo}

Os teores de minerais nas sementes de feijão comum são influenciados, além da variação genética, pelas condições ambientais de cultivo, especialmente pelo tipo e pela composição química do solo e pela interação genótipos x ambientes. Assim, este trabalho foi realizado para verificar se os teores de zinco e ferro são afetados pela safra de cultivo. Dez linhagens com teores elevados de ferro e zinco e dez com baixos teores foram avaliadas durante três safras: "águas" de 2009/2010 (semeadura em novembro); "seca” de 2010 (semeadura em fevereiro) e "inverno" de 2010 (semeadura em julho), em Lavras (MG). 0 delineamento experimental utilizado foi o de blocos casualizados com três repetições e parcelas constituídas de duas linhas de dois metros, espaçadas de 0,50 m. As sementes colhidas foram avaliadas quanto aos teores dos minerais, ferro e zinco. Os maiores teores de ferro e zinco foram observados na safra do inverno e os menores na safra da seca, semeadura em fevereiro. Observou-se que, na média das três safras, as linhagens classificadas como de alto teor de ferro e zinco, tiveram quantidade de ferro $11,0 \%$ e de zinco 6,8\% acima das de baixo teor. A interação linhagens x safras ocorre, porém, sua interferência não é grande na identificação dos grupos com alto e baixo teor dos dois nutrientes.

Palavras-chave: Phaseolus vulgaris L.; qualidade nutricional; ambiente de cultivo.

\section{INTRODUCTION}

The common bean (Phaseolus vulgaris L.) is the most important legume used in daily nourishment for more than 300 million people (BeEBe, 2010). Brazil is the largest producer in the world and also the largest consumer, $16 \mathrm{~kg} /$ inhabitant/year, with a small exportable surplus (EMBRAPA, 2011). Its importance in human nutrition results comes from the fact that it is an important source of protein, as well as has high levels of various minerals, among which are iron and zinc (WANG et al., 2003). 
In humans, iron is essential for prevention of anemia and in the functioning of various metabolic processes, while zinc is essential for adjusting development and sexual maturity, gastro intestinal resistance and resistance to respiratory infections, especially in children (Bouis, 2003). These two minerals are very important, principally because a large part of the population does not have access to foods, many of them of animal origin, which supply these needs. Thus, for some time already, emphasis has been given to breeding for increasing the mineral content in bean grains, what is known as biofortification (BEEBE, 2010). In these studies, it has been observed that there is genetic variability for the traits that confer nutritional quality to beans, making it possible to select lines with high nutritional value (BEEBE et al., 2000; Mesquita et al., 2007; Ribeiro et al., 2008).

Nevertheless, it has also been observed that in addition to genetic variation, the mineral contents in the seeds are influenced by environmental crop conditions, especially by the soil type and chemical composition and by the genotypes by environments interaction (Moraghan et al., 2002; Сichy et al., 2005). The genotypes by environments interaction has been a large complicating factor in breeding studies with a view toward improvement, principally in bean grain yields, among other traits (Allard and Bradshaw, 1964; Ramalho et al., 1998; Carbonell et al., 2004; Pereira et al., 2009). However, no report was found regarding the influence of the crop growing period on the iron and zinc mineral contents.

This confirms the importance of performing more detailed studies on the influence of the season on the contents of these minerals because a bean plant with greater nutritional value may be obtained depending on the crop growing period. Therefore the objective of the present study was to verify if the zinc and iron contents are affected by the crop growing period.

\section{MATERIAL AND METHODS}

In previous assessment, ten lines that present high iron and zinc contents and ten lines with low contents were identified by SiLva et al. (2010).

The twenty lines were assessed for three seasons: "wet season" of 2009/2010 (sowing in November); "dry season" of 2010 (sowing in February) and "winter season" of 2010 (sowing in July). The experimental design used was randomized blocks with three replications and plots consisting of two rows of two meters, spaced at 0.50 meters. For fertilization, $400 \mathrm{~kg} \mathrm{ha}^{-1}$ of the formula 8-28-16 of $\mathrm{N}, \mathrm{P}_{2} \mathrm{O}_{5}$ and $\mathrm{K}_{2} 0$ were used at sowing and $150 \mathrm{~kg} \mathrm{ha}^{-1}$ in cover 25 days after sowing. In the "dry" and winter seasons, sprinkler irrigation was utilized whenever necessary. After harvest, seeds were dried naturally until reaching 13\% moisture. Lines were assessed in regard to iron and zinc mineral contents.
For performance of chemical analyses of the minerals, a sample of approximately 50 grams was removed from each plot and the samples were ground in a micro cutting mill until obtaining particle size of less than $1 \mathrm{~mm}$ and they were stored in plastic packages, duly sealed and labeled, and conserved in a cooler up to the time of performing laboratory analyses.

For analysis of the zinc and iron minerals, hot nitro perchloric digestion was performed with $0.5 \mathrm{~g}$ from each sample. At the end of digestion, the volume of the extract was completed to $15 \mathrm{~mL}$ with deionized water. In this digestion, there is the removal of the elements of the organic compounds of the sample or adsorbed to them. Analyses were performed by atomic absorption spectrophotometry using the apparatus model SpectrAA 110 (Varian INE), calibrated under specific wavelength conditions, aperture and gas mixture for each element, using the procedures described by Malavolta et al. (1997).

After performance of analyses, the data were corrected to a dry basis by means of the moisture testing technique, which consists of water loss of the sample through desiccation in temperatures from 100 to $105^{\circ} \mathrm{C}$ (AOAC, 2005).

The data were submitted to analysis of variance using the statistical program SAS version 9.0 of STATISTICAL Analysis Systems (2008). For data analysis, all the effects were considered as fixed. Afterwards, joint analysis of variance of the data referring to the three seasons was performed using the following model:

$Y_{\mathrm{ijk}}=m+l_{\mathrm{i}}+b_{\mathrm{i}(\mathrm{k})}+s_{\mathrm{k}}+\left(l l_{\mathrm{ik}}+e_{\mathrm{ijk}}\right.$ in which: $Y_{\mathrm{ijk}}:$ value observed in the plot which received line $i$, in replication $j$, in season $k$; $m$ : general mean of the experiment; $l_{i}$ : effect of line $i$, with $i=1,2, \ldots, 20 ; b_{j(k)}$ : effect of replication $j$, with $j=1,2$ and 3 , within season $\mathrm{k}$; $\mathrm{s}_{\mathrm{k}}$ : effect of season $k$, with $k=1,2$ and 3; $(l s)_{\mathrm{ik}}$ : effect of interaction line $i$ and season $k ; e_{\mathrm{ijk}}$ : experimental error associated with observation $Y_{\mathrm{ijk}}$, assuming that errors are independent and normally distributed, with zero mean and variance $\sigma_{e}^{2}$.

The component of lines by seasons interaction was decomposed in simple and complex parts by the methodology presented by Cruz et al. (2004):

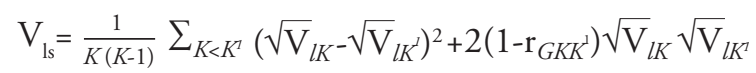

in which:

$\mathrm{V}_{1 \mathrm{l}}$ : variance of lines by seasons interaction; $\mathrm{K}$ : number of seasons; $\mathrm{V}_{\mathrm{lk}}$ : genetic variance among the lines in season $\mathrm{k} ; \mathrm{V}_{\mathrm{lk}}$ : genetic variance among the lines in season $\mathrm{k}$; $\mathrm{r}_{\mathrm{Gkk}}$ : correlation among the lines in seasons $\mathrm{k}$ and $\mathrm{k}$ '.

The means were compared by the SсотT and KNOTT (1974) grouping test. To estimate the contribution of each line to the interaction in the mean of the seasons the methodology presented by WRICKE (1965) was employed, using the software Genes (Cruz, 2006). 


\section{RESULTS AND DISCUSSION}

A significant difference was found among the environments (seasons), a condition which is indispensable for that which is proposed in this study. The greatest iron and zinc contents were observed in the winter season and the lowest in the dry season, with sowing in February (Table 1). As the experimental area and crop management procedures in the three seasons were the same, the main difference among them must be attributed to climatic conditions (Figure 1). The three bean crop growing periods presented highly contrasting climatic conditions. The most notable differences may be observed in rainfall and relative humidity.

Although the experiments of the "dry" and winter seasons received supplemental sprinkler irrigation, the microclimate formed through irrigation is not comparable to that provided through the occurrence of rainfall, principally in the winter season carried out from July to October, when the relative humidity is very low. In this winter season, the most significant rainfall only occurred at the end of the crop cycle when it is already in the maturation phase. In addition, the mean temperatures in the winter season were nearly always below $20^{\circ} \mathrm{C}$. The effect of water stress on iron and zinc contents was evaluated by BASSINELlo et al. (2010) in a study involving 72 lines of beans. The authors found that with a smaller quantity of water, the content of the two nutrients increased, in agreement with the present study.

The source of variation lines was significant $(\mathrm{p}<0.01)$. In decomposition, it was found that the effect of the groups was also highly significant $(p<0.01)$. It was observed that in the mean of the three harvest periods, the lines previously identified as having high iron and zinc contents exhibited a quantity of iron $11.0 \%$ and of zinc $6.8 \%$ above those of low content (Table 1). It was also found that the seasons by groups interaction was significant $(p<0.05)$; however, the group classified as having high content always exhibited a greater mean in the three seasons for both nutrients, indicating that this interaction should not affect the work of plant breeders.

There was a difference among the lines of both the high zinc and iron content group and the low content group. The lines by seasons interaction was significant $(\mathrm{p}<0.05)$ in all cases. In its decomposition, it was found to be predominantly complex. This is an unfavorable condition for selection because it changes classification of the lines in the different environments (VencovsKY and Barriga, 1992; Cruz et al., 2004). However, the genotypes $\mathrm{x}$ environments interaction can be exploited in the selection of genotypes for a particular region or environment. In this case, the interaction is capitalized by increasing the value of phenotypic character for that specific place. Additionally, existing changes in the classification

Table 1. Means for the iron and zinc contents $\left(\mathrm{mg} \mathrm{kg}^{-1}\right)$ of twenty bean lines selected for high and low iron and zinc contents in three crop growing periods ("wet season" period 2009/2010, "dry season" period of 2010 and winter of 2010)

\begin{tabular}{|c|c|c|c|c|c|c|c|c|c|c|c|c|c|c|c|c|}
\hline \multirow[b]{2}{*}{ Line } & \multicolumn{4}{|c|}{ Rainy 09/10 } & \multicolumn{4}{|c|}{ Dry 2010} & \multicolumn{4}{|c|}{ Winter 2010} & \multicolumn{4}{|c|}{ Mean } \\
\hline & Iron & & Zinc & & Iron & & Zinc & & Iron & & Zinc & & Iron & & Zinc & \\
\hline P-180 & 99.84 & b & 47.37 & $\mathrm{a}$ & 82.62 & $\mathrm{a}$ & 43.45 & $\mathrm{a}$ & 116.47 & $\mathrm{a}$ & 54.35 & a & 99.64 & $\mathrm{a}$ & 48.39 & $\mathrm{a}$ \\
\hline $\mathrm{R}-1$ & 89.33 & d & 44.62 & $b$ & 87.21 & $\mathrm{a}$ & 42.00 & $\mathrm{a}$ & 116.04 & $\mathrm{a}$ & 56.86 & a & 97.53 & $\mathrm{a}$ & 47.83 & $\mathrm{a}$ \\
\hline Linea 29 & 96.23 & c & 40.23 & c & 86.72 & $\mathrm{a}$ & 37.88 & $b$ & 100.03 & $b$ & 46.74 & c & 94.33 & $\mathrm{a}$ & 41.62 & c \\
\hline ICA-Pijão & 105.90 & $\mathrm{a}$ & 48.94 & a & 83.29 & a & 43.25 & $\mathrm{a}$ & 103.68 & $\mathrm{a}$ & 49.96 & $b$ & 97.62 & $\mathrm{a}$ & 47.39 & $\mathrm{a}$ \\
\hline AN 910523 & 95.92 & c & 45.29 & $b$ & 88.62 & $\mathrm{a}$ & 43.64 & $\mathrm{a}$ & 105.25 & $\mathrm{a}$ & 55.21 & $\mathrm{a}$ & 96.60 & $\mathrm{a}$ & 48.05 & $\mathrm{a}$ \\
\hline Milionário & 89.13 & d & 41.60 & c & 83.88 & $\mathrm{a}$ & 41.53 & $\mathrm{a}$ & 112.63 & $\mathrm{a}$ & 51.99 & $b$ & 95.20 & $\mathrm{a}$ & 45.04 & $b$ \\
\hline RP-1 & 79.76 & $f$ & 38.74 & $d$ & 75.66 & b & 38.07 & $b$ & 104.07 & $\mathrm{a}$ & 45.99 & c & 86.50 & b & 40.93 & c \\
\hline Capixaba Precoce & 91.17 & d & 43.25 & $b$ & 77.57 & $b$ & 44.15 & a & 103.37 & $\mathrm{a}$ & 56.04 & a & 90.70 & $\mathrm{a}$ & 47.81 & $\mathrm{a}$ \\
\hline Esal 651 & 80.31 & $f$ & 37.29 & $d$ & 72.55 & c & 37.17 & $b$ & 99.10 & $b$ & 51.80 & $b$ & 84.00 & b & 42.09 & c \\
\hline Ouro & 92.78 & d & 36.58 & $d$ & 79.60 & $b$ & 39.21 & $b$ & 107.05 & $\mathrm{a}$ & 49.72 & $b$ & 93.14 & $\mathrm{a}$ & 41.84 & c \\
\hline High mean & 92.04 & & 43.39 & & 81.77 & & 41.04 & & 106.77 & & 51.87 & & 93.53 & & 45.43 & \\
\hline MA-II-22 & 84.51 & e & 38.51 & d & 64.39 & c & 39.57 & $b$ & 91.92 & $b$ & 45.57 & c & 80.27 & $b$ & 41.22 & c \\
\hline Paraná & 77.61 & $f$ & 34.23 & e & 65.56 & c & 34.74 & $b$ & 100.94 & $b$ & 47.17 & c & 81.40 & b & 38.71 & c \\
\hline Negrito & 84.51 & $f$ & 40.70 & c & 75.33 & $b$ & 38.00 & $b$ & 101.80 & $b$ & 53.06 & $\mathrm{a}$ & 87.20 & b & 43.92 & $b$ \\
\hline Esal 543 & 74.43 & e & 43.05 & $b$ & 66.76 & c & 40.43 & a & 97.60 & $b$ & 54.66 & $\mathrm{a}$ & 79.60 & $b$ & 46.05 & $b$ \\
\hline BP-28 & 79.41 & f & 41.88 & c & 63.90 & c & 34.74 & $b$ & 96.50 & $b$ & 49.10 & $b$ & 79.90 & b & 41.91 & c \\
\hline BRS Pitanga & 79.41 & $f$ & 42.15 & c & 69.88 & c & 38.66 & b & 93.10 & $b$ & 53.49 & a & 80.80 & b & 44.77 & $b$ \\
\hline BRS Valente & 78.86 & $f$ & 42.07 & c & 77.45 & $b$ & 40.08 & $\mathrm{a}$ & 108.74 & $\mathrm{a}$ & 51.37 & $b$ & 88.35 & $b$ & 44.51 & $b$ \\
\hline Batatinha & 95.92 & c & 47.84 & a & 63.72 & c & 34.74 & b & 84.98 & $b$ & 36.55 & d & 81.54 & b & 39.71 & c \\
\hline IAC-Aruã & 86.15 & e & 45.45 & b & 70.58 & c & 37.33 & b & 99.17 & $b$ & 46.35 & c & 85.30 & b & 43.04 & c \\
\hline Esal 516 & 77.37 & $f$ & 38.82 & d & 76.86 & $b$ & 35.05 & $b$ & 109.64 & $\mathrm{a}$ & 44.90 & c & 87.96 & b & 39.59 & c \\
\hline Low mean & 81.82 & & 41.47 & & 69.44 & & 37.33 & & 98.44 & & 48.22 & & 83.23 & & 42.34 & \\
\hline General mean & 86.93 & & 41.94 & & 75.61 & & 39.19 & & 102.62 & & 50.05 & & 88.40 & & 43.73 & \\
\hline
\end{tabular}

Means followed by the same letter in the column belong to the same group by the Scott and Knott (1974) test, $\mathrm{p} \leq 0.05$. 
of the genotypes in different environmental conditions, due to the predominance of complex interaction, does not preclude the selection of genotypes with broad adaptation, which present stable behavior for the traits analyzed through the considered environments (VENCOVSKY and BARRIGA, 1992).

This change in classification of the lines may be observed in table 1 . However, although there was change in the classification of the lines from one season to another, cases in which a line considered to be of high content was classified in a low group, or vice versa, were very restricted. A finding that reinforces this observation is that the screening of the lines in the previous stage was only in the dry season (SiLva et al., 2010). Even so, most of the lines classified as having high or low iron and zinc content maintained their performance, reinforcing the idea that, in this case, the interaction should not affect the work of the plant breeders.

In a study performed by TrYPHONE and NCHIMBIMsolla (2010), it was observed that iron and zinc contents

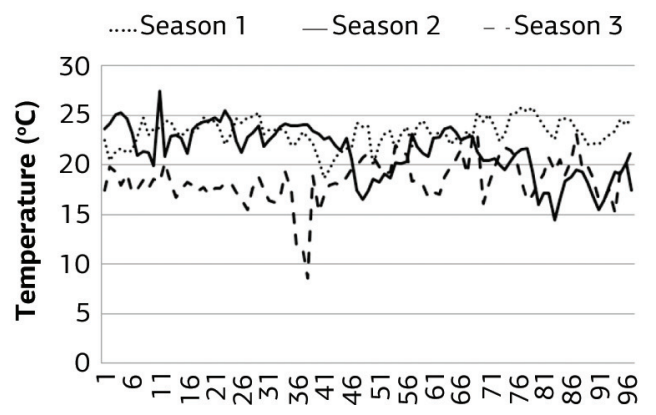

(a)

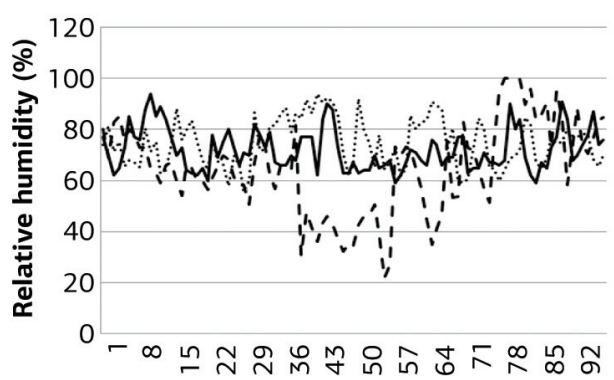

(b)

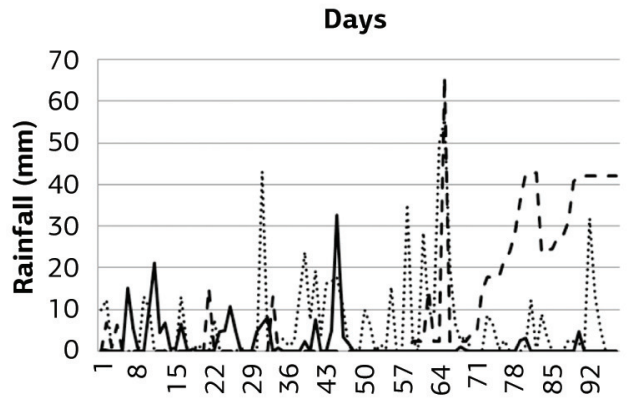

Figure 1. Daily means of air temperature (a) and relative humidity (b), and rainfall (c) and during the seasons in which the bean lines were assessed ( $1=$ rainy period $09 / 10 ; 2=$ dry period 2010 and $3=$ winter 2010). of lines grown in two different locations were not similar, indicating that the lines must be assessed in a greater number of environments so that those that exhibit stable contents of these minerals in the seeds may be selected. ARAújo et al. (2003), for their part, found genotypes by environments interaction for iron content in assessment of 25 genotypes grown in three locations in the State of Paraná. These results showed a differentiated response of the bean cultivars to assessment locations, in response to differences in soil and in environmental conditions.

To better clarify the interaction, the contribution of each line to this parameter was estimated (Table 2). It may be seen that the behavior of a few lines was expressive in contributing to the interaction. The 'Batatinha' was that which most contributed to the interaction in the content of the two minerals. In the case of zinc, this contribution was nearly half of the total interaction. This line obtained the lowest iron and zinc contents in the season in which it was selected (SiLva et al., 2010), while in the rainy season 2009/2010, for example, it was among those of the greatest content.

These results confirm that although the interaction was significant and for the most part complex, the effect of this interaction in identification of lines with high or low iron and zinc content was small. The greatest changes in classification of the lines occurred for zinc. Nevertheless, it is important to comment that in selection of lines with high and low mineral contents, the classification in regard to iron content was considered in first place. Thus, change in classification of the lines in regard to zinc content is justifiable because, in spite of there being positive correlation

Table 2. Contribution, in \%, of 20 bean lines selected for high and low iron and zinc content assessed in the "rainy" season 2009/2010, "dry" season 2010 and winter season 2010, for the lines by seasons interaction

\begin{tabular}{llcc} 
Line & Classification & Zinc & Iron \\
\hline P-180 & high & 0.23 & 2.09 \\
\hline R-1 & high & 1.19 & 3.26 \\
Linea 29 & high & 0.58 & 8.40 \\
\hline ICA-Pijão & high & 6.60 & 12.40 \\
\hline AN 910523 & high & 0.43 & 4.15 \\
\hline Milionário & high & 1.08 & 2.56 \\
\hline RP-1 & high & 1.19 & 3.26 \\
\hline Capixaba Precoce & high & 3.14 & 0.47 \\
\hline Esal 651 & high & 5.37 & 0.57 \\
\hline Ouro & high & 4.70 & 0.14 \\
\hline MA-II-22 & low & 3.40 & 3.70 \\
\hline Paraná & low & 3.15 & 3.28 \\
\hline Negrito & low & 3.10 & 0.19 \\
\hline Esal 543 & low & 2.40 & 2.13 \\
\hline BP-28 & low & 2.79 & 1.29 \\
\hline BRS Pitanga & low & 2.32 & 0.54 \\
\hline BRS Valente & low & 0.19 & 8.07 \\
\hline Batatinha & low & 49.00 & 29.80 \\
\hline IAC-Arua & low & 7.30 & 0.70 \\
\hline Esal 516 & low & 0.53 & 10.70 \\
\hline
\end{tabular}


among these two minerals $(\mathrm{r}=0.87)$, some lines with high iron levels did not present such high levels for zinc.

It is important to emphasize the need to study the inheritance of the characters in a quantitative study, using, for example, partial diallel between genotype groups for contrasting mineral content.

\section{CONCLUSION}

Zinc and iron contents are affected by harvest season. The greatest contents were observed in the winter season and the lowest in the dry season. On average, the lines classified as having high iron and zinc content exhibited a quantity of iron $11.0 \%$ and of zinc $6.8 \%$ higher than those of low content. The lines by seasons interaction occurs; however, its interference in identification of the groups with high and low content of the two nutrients is not high.

\section{ACKNOWLEDGMENTS}

The authors wish to acknowledge the Coordenação de Aperfeiçoamento de Pessoal de Nível Superior (CAPES), the Fundação de Amparo à Pesquisa do Estado de Minas Gerais (FAPEMIG) and the Conselho Nacional de Desenvolvimento Científico e Tecnológico (CNPq) for research scholarships and financial support.

\section{REFERENCES}

ALLARD, R.W.; BRADSHAW, A.D. Implications of genotypesenvironmental interactions in applied plant breeding. Crop Science, v.4, p.503-508, 1964.

ARAÚJO, R.; MIGLIORANZA, E.; MONTALVAN, R.; DESTRO, D.; GONÇALVES-VIDIGAL, M.C.; MODACIRINO, V. Genotype x environment interaction effects on the iron content of common bean grains. Crop Breeding and Applied Biotechnology, v.3, p.269-274, 2003.

ASSOCIATION OF OFFICIAL ANALYTICAL CHEMISTS - INTERNATIONAL [AOAC]. Official Methods of Analysis. 18.ed. Gaithersburg, AOAC, MD, USA, 2005.

BASSINELLO, P.Z.; OLIVEIRA, B.R; NOBREGA, L.N.N; SILVA, W.M.R.; PEREIRA, H.S.; MELO, L.C.; DEL PELOSO, M.J. Effect of the environment on zinc and iron levels in common beans. Annual Report of the Bean Improvement Cooperative, v.10, p.146-147, 2010.

BEEBE, S. Bean Biofortified. HarvetPlus. 2010. Disponível: <http://www.harvestplus.org/publications> Acesso em: 27/1/2010.

BEEBE, S.; GONZALEZ, V.; RENGIFO, J. Research on trace minerals in the common bean. Food and Nutrition Bulletin, v.21, p.387-391, 2000.
BOUIS, H.E. Micronutrient fortification of plants through plant breeding: can it improve nutrition in man at low cost? Proceedings of the Nutrition Society, v.62, p.403-411, 2003.

CARBONELL, S.A.M.; AZEVEDO FILHO, J.A.; DIAS, L.A.S.; GARCIA, A.A.F.; MORAIS, L.K. Common bean cultivars and line interactions with environments. Scientia Agricola, v.61, p.169-177, 2004.

CARBONELL, S.A.M.; CHIORATO, A.F.; RESENDE, M.D.V.; DIAS, L.A.S.; BERALDO, A.L.A.; PERINA, E.F. Stability of common bean cultivars and lines in different environments in the state of São Paulo. Bragantia, v.66, p.193-201, 2007.

CICHY, K.A.; FORSTER, S.; GRAFTON, K.F.; HOSFIELD, G.L. Inheritance of seed zinc accumulation in navy bean. Crop Science, v.45, p.864-870, 2005.

CRUZ, C.D. Programa Genes: Estatística experimental e matrizes. Viçosa: Ed. UFV, 2006.

CRUZ, C.D.; REGAZZI, A.J.; CARNEIRO, P.C.S. Modelos biométricos aplicados ao melhoramento genético. Viçosa: Ed. UFV, 2004.

EMBRAPA - Arroz e Feijão. 2011. Disponível em: <http://www. cnpaf.embrapa.br/feijao/sistemasdeproducao/index.htm> Acesso em: 16/2/ 2011, 2011.

MALAVOLTA, E.; VITTI, G.C.; OLIVEIRA, S.A. Avaliação do estado nutricional das plantas: princípios e aplicaçóes. 2.ed. Piracicaba: POTAFOS, 1997. 319p.

MESQUITA, F.R.; CORRÊA, A.D.; ABREU, C.M.P.A.; LIMA, R.A.Z.L.; ABREU, A.F.B. Bean (Phaseolus vulgaris L.) lines: chemical composition and protein digestibility. Ciência e Agrotecnologia, v.31, p.1114-1121, 2007.

MORAGHAN, J.T.; PADILLA, J.; ETCHEVERS, J.D.; GRAFTON, K.; ACOSTA-GALLEGOS, J.A. Iron accumulation in seed of common bean. Plant and Soil, v.246, p.175-183, 2002.

PEREIRA, H.S.; MELO, L.C.; FARIA, L.C.; DEL PELOSO, M.J.; COSTA, J.G.C.; RAVA, C.A.; WENDLAND, A. Adaptability and stability of common bean genotypes with carioca grain type for central Brazil. Pesquisa Agropecuária Brasileira, v.44, p.29-37, 2009.

RAMALHO, M.A.P.; ABREU, A.F.B.; SANTOS, P.S.J. Interaction genotype $\mathrm{x}$ seasons, years and locations in the evaluation of bean cultivars in the South and Alto Paranaiba in Minas Gerais. Ciência e Agrotecnologia, v.22, p.176-181,1998.

RIBEIRO, N.D.; JOST, E.; POSSEBON, S.B.; CARGNELUTTI FILHO, A. Adaptability and stability of registred bean cultivars in different growing seasons to central depression region of Rio Grande do Sul. Ciência Rural, v.34, p.1395-1400, 2004.

RIBEIRO, N.D.; JOST, E.; CERUTTI, T.; MAZIERO, S.M.; POERSCH, N.L. Micromineral composition of common bean cultivars and its application in crop breeding. Bragantia, v.67, p.267-273, 2008. 
SAS INSTITUTE. SAS/STAT 9.2 User's guide. Cary: SAS Institute, 2008.

SCOTT, A.J.; KNOTT, M.A. Cluster analysis method for grouping means in the analysis of variance. Biometrics, v.30, p.507-512, 1974.

SILVA, C.A.; ABREU, A.F.B.; RAMALHO, M.A.P., CORREA, A.D.; MAIA, L.G.S. Genetic variability for protein and minerals content in common bean lines (Phaseolus vulgaris L.). Annual Report of the Bean Improvement Cooperative, v.53, p.144-145, 2010.

TRYPHONE, G.M; NCHIMBI-MSOLLA, S. Diversity of common bean (Phaseolus vulgaris L.) genotypes in iron and zinc contents under screenhouse conditions. African Journal of Agricultural Research, v.5, p.738-747, 2010.

VENCOVSKY, R.; BARRIGA, P. Genética Biométrica no Fitomelhoramento. Ribeirão Preto: Sociedade Brasileira de Genética, 1992. 496p.

WANG, T.L., DOMONEY, C., HEDLEY, C.L., CASEY, R., GRUSAK, M.A. Can we improve the nutritional quality of legume seeds? Plant Physiology, v.131, p.886-891, 2003.

WRICKE G. Zur Berechnung der Ökovalenz bei Sommerweizen und Hafer. Pflanzenzüchtung, v.52, p.127-138, 1965. 